\title{
Placing Rwanda's agriculture boom: trust, women empowerment and policy impact in maize agricultural cooperatives
}

\author{
John Elliot Meador ${ }^{1}$ (D) $\cdot$ David O'Brien $^{2}$
}

Received: 13 July 2018 / Accepted: 21 June 2019 / Published online: 26 July 2019

(C) The Author(s) 2019

\begin{abstract}
Rwanda has experienced significant economic growth following the 1994 Genocide. This growth is attributed to the expansion of its agricultural sector, specifically farming intensification and the government's focus on creating strong agriculture cooperatives. While Rwanda's economic development has been impressive, many academics have argued that Rwanda's growth comes at the cost of an authoritarian governmental regime, whose policies have too heavy a hand in the daily activities of smallholder farming. This study measures smallholder maize farmer loyalty to their cooperatives using the net promoter scores of five different cooperatives. Results differ from much of the recent research on smallholder farmers in Rwanda in that most cooperative members have high levels of trust in their cooperative leaders. Cooperative members who have high levels of trust in their cooperative president, board and the Government of Rwanda are more likely to recommend their cooperative to friends and family. Furthermore, women cooperative members have higher levels of trust in cooperative leadership, the Government of Rwanda and almost all agricultural input providers mentioned in the study. Findings suggest that cooperative policy, most notably the mandatory inclusion of high numbers of women in cooperative decision-making, is helping to promote strong agricultural institutions as well as sustainable economic development.
\end{abstract}

Keywords Rwanda $\cdot$ Agriculture $\cdot$ Cooperative $\cdot$ Social capital $\cdot$ Net promoter score

\section{Introduction}

Rwanda has undergone an enormous transformation since the 1994 Genocide, in which between 600,000 and 800,000 Tutsi and moderate Hutu were murdered and virtually all of its governmental institutions were destroyed (For a full review of the socio-political history of the region and discussion of the Rwandan Genocide see Prunier's (2008) Africa's world war: Congo, the Rwandan genocide, and the making of a continental catastrophe). In the almost two and a half decades following the genocide, ambitious government policies aimed to combat poverty and bring Rwanda into the global economy have been implemented. These policies, especially as they

John Elliot Meador

Elliot.meador@ sruc.ac.uk

David O'Brien

obriendj@missouri.edu

1 Scotland's Rural College, W Mains Rd, Edinburgh EH9 3JG, UK

2 University of Missouri, 109 Gentry Hall, Columbia, MO, USA pertain to food production, along with support from international donors, have produced significant economic gains in a relatively short period of time. From 2001 to 2015 the GDP growth rate in Rwanda has been around $8 \%$. The poverty rate declined from $44 \%$ in 2011 to $39 \%$ in 2014, while the Gini Coefficient indicator of inequality dropped from 0.49 to 0.45 during the same period (World Bank 2017).

Much of the success in poverty reduction and economic growth can be attributed to a stable political environment in Rwanda and, especially in contrast to many other sub-Saharan African nations, a low level of political corruption. Moreover, Rwanda has received praise from academics and advocacy groups for its policies to mandate a strong representation of women in government. The Government of Rwanda officially established national gender quotas in government in the Constitution signed in 2003. Legislation requires that $30 \%$ of the representative government consists of women. One hope from this is to increase the influence of women in national and local governance, which has seen some success (Burnet 2008). To put this in perspective, the World Bank (2018) ranks Rwanda first according to the percentage of women in parliaments in the world in 2018 - a title Rwanda 
has held since 2012. The proportion of seats held by women in the Rwanda Parliament has steadily increased from $17.1 \%$ in 1997 to $63.8 \%$ in 2016. The Government of Rwanda's policy on gender equality has also been successful in symbolically inspiring women to pursue leadership positions in their local communities, and this has led to a higher representation of women in government than is constitutionally required. This policy also helped to produce a substantial increase in women membership and leadership in agricultural cooperatives; a serious reservation being, however, that gender equality does not exist in homes, and that women representation in government is still highly influenced by the government, which oversees all aspects of the electoral process and women candidacy (Burnet 2011). Nonetheless, it is impressive that in June of $2016,64 \%$ of the members of the national parliament were women (Warner 2016). Moreover, women in the cooperative focus groups involved in the current study were as assertive as the men in presenting their points of view.

There is no question, however, that the country's current stability has been achieved with authoritarian, one-party rule. The current governing party, the Rwandan Patriotic Front headed by President Paul Kagame, has been in power since its military leaders ended the genocide in summer 1994, and has implemented a strict policy which has been called, "... the world's boldest experiment in transitional justice, comprehensive land tenure and agricultural reform, forced villagization, a de facto ban on ethnic identity, reeducation of the population, and the systematic redrawing and renaming of Rwanda's territory, among other things" (Straus and Waldrof 2011, p. 4).

These policies are set within the framework of the government's "Genocide Remembrance" policy in which strong laws regulating public behavior are seen as the only way to prevent a re-emergence of inter-ethnic conflict and violence (Clark 2018). Critics, however, question whether this authoritarian policy will produce long-term stability in the agricultural sector, let alone build the civil society institutions of liberal democracy (Huggins 2014).

Rwandan agricultural policy, in which cooperatives play a key role, has been subject to the same mixed reviews as those given to overall government economic policy. On the one hand, it is clear that there have been substantial gains in the agricultural sector and that agricultural policy is viewed as an essential feature of economic development. The Government of Rwanda holds considerable influence in the organization of the agricultural sector, including land ownership, the purchase of agricultural inputs and decisions on what crops to grow. This high level of control is found in nearly all levels of the agriculture supply chain, and it is clearly moving the country towards a more modern agricultural sector in which land and farms are privatized (Gready 2010).

Indeed, growth in Rwanda's agriculture sector has been impressive. In 2007 the Government of Rwanda implemented the Crop Intensification Program (CIP), and, following positive market growth, the government has pushed for further intensification practices, a flagship of which is the implementation of agriculture cooperatives in the country (Kathiresan 2011). Figure 1 illustrates the cumulative growth of new cooperatives in Rwanda. Since 2009 - the earliest year with reliable data - there has been a substantial growth of cooperatives. As of 2018 there are just under 8000 cooperatives listed in the Rwanda Cooperative Agency cooperative directory database. On average, 790 (sd = 226.0) new cooperatives are added each year. Cooperatives were added at similar rates across provinces at first, but since 2013 cooperatives in the West Province have been created at higher rates than in other provinces. As of 2018, the West Province has 2010 cooperatives. Kigali, the capital, comprised of mostly urban areas, has the lowest number of cooperatives registered in the dataset at 1,156 .

There is evidence that this growth is due, in part at least, to the cooperative membership for smallholder farmers when compared to non-member farmers. Verhofstadt and Maertens (2014) found that farm income per worker increased by about $40 \%$ for cooperative members when compared to non-members. However, the Government of Rwanda's heavy hand in agriculture policy means that government policy is likely to influence the social networks of peasant farmers, and thus may influence the way in which members participate in their cooperative. While some academics do acknowledge that this approach to economic development may, in fact, be working or, at least, one cannot justifiably say that it will not work based on evidence presented thus far (Harrison 2016) - others suggest that it has had a negative impact on the social relationships and trust among small-holding farmers. Critics point to the overall lack of dialogue between the government and farmer, with interactions between the two more often happening on an ad hoc basis (Gready 2010). This lack of communication, it is argued, results in a one-way flow of information, which is often communicated to the farmer through the cooperative. Furthermore, Huggins (2009) contends that cooperative membership was in many respects compulsory for smallholder farmers in 2009 just after implementation of the CIP in 2007, and that members, "know little about how they [the cooperatives] function or what membership entails. .. [they] expressed concern about a lack of transparency, recounting that in the past, cooperatives had collapsed due to corruption" (Huggins 2009, p. 300). Huggins goes on to argue that the lack of autonomy and agency of small-holder farmers in Rwanda, leads to "significant degrees of dissatisfaction" of cooperative members (Huggins 2014, p. 380).

These conflicting assessments of Rwandan agricultural policies, and in particular cooperative development, poses an important research question: to what extent do Rwandan smallholder farmer members view their cooperatives in a positive or negative way? Are they satisfied with the performance of these cooperatives, and, most important, do women and men members trust the cooperatives to pursue their interests in the long-run? 
Fig. 1 Cumulative growth of Rwandan Cooperatives since 2009 by Province

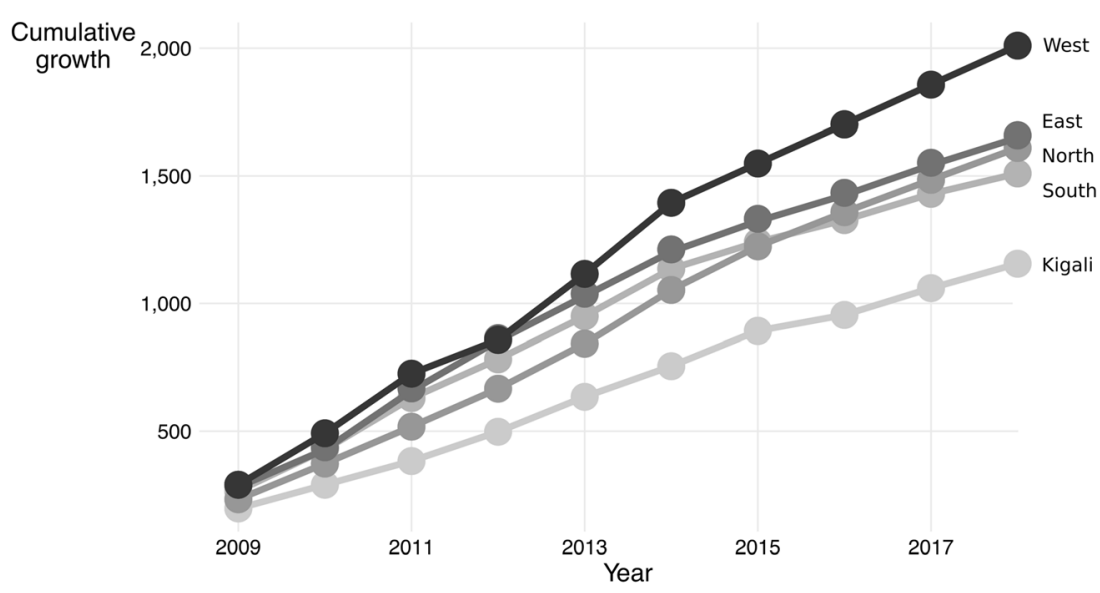

Data are from the Rwanda Cooperative Agency website 2018

\section{Theory}

This study uses social capital theory as a theoretical framework due to the importance of social capital in building successful and sustainable agriculture cooperatives in the West and in the Global South. Given Rwanda's recent history, which culminated with genocide in 1994 and civil unrest in the year immediately following, it is important to review the theoretical components of social capital - namely, bonding and bridging social capital. Special attention is given to the role of government policy and institutions in helping to build and promote social capital in the form of trust.

Agriculture cooperatives emerged in the nineteenth century in Western countries to provide collective, countervailing power for small farmers in the marketplace. In the United States, for example, cooperatives historically provided leverage vis-à-vis railroads that shipped farmers' grain, as well as silo operators who purchased that grain and input suppliers, who provided seeds, fuel and fertilizer at lowered costs. A critical element in the formation of these cooperatives was their ability to maintain the loyalty of their members through high levels of trust that was generated through long-term cooperation in small-town schools, churches and farms (Schneiberg et al. 2008).

Trust is a form of social capital that can produce both physical and human capital (Coleman 1988). Putnam (1995, p. 225) explains that "social capital refers to features of social organization such as networks, norms, and social trust that facilitate coordination and cooperation for mutual benefit". Thus, cooperatives in the United States have had a social capital advantage over other types of organizations insofar as the trust of their members permits them to engage in long-range planning without the pressures for immediate return that plague investor-owned firms. Agricultural cooperatives have been able to introduce new technologies and new market opportunities in areas with which their farmer-members were previously unfamiliar; with sources of information that were outside of the purview of their small-town experience. In effect, then, cooperatives were able to use the initial bonding social capital trust based on their small-town experience to build bridging social capital (Woolcock and Narayan 2000) that, in turn, increased their ability to build successful business models. Eventually cooperatives were able to successfully lobby to pass legislation at the state and national levels, such as exemption from anti-trust laws, which provided farmers with additional advantages (Cook 1995; Schneiberg et al. 2008).

Still today, multi-million-dollar cooperatives depend upon the trust of their members in a way that is not found in investor-owned firms. In a recent study of cooperative performance in the U.S., the level of social capital, measured by structures for communication between members and the board, especially feedback loops so that members could provide input into board decisions, was found to be a more important predictor of member satisfaction and overall financial success than some strictly accounting factors that are found to be more important in the success of investor-owned firms (Cook \& Burress 2013). These social capital advantages have made it possible for cooperatives to be more resilient than investor-owned firms in adapting to the ups and downs in the macro-economies and markets in which they operate.

One goal of cooperative development projects in SubSaharan Africa is to provide countervailing power for farmer-members vis-à-vis input suppliers and processors something they share with cooperatives in the developed world. Countervailing power eventually provides for vertical integration into the value chain, whereby cooperatives begin to operate processing facilities themselves (Meador et al. 2016; O'Brien et al. 2013). These emerging cooperatives also share the need to develop and maintain social capital among their members to induce them to adopt new agricultural technologies as well as invest in long-term capitalization projects. The latter is especially difficult because it implies foregoing some immediate gains for some future benefit that is by no means guaranteed. Moreover, such long-term investments require accessing information and working with organizations 
and individuals with whom village-level cooperative members are not familiar. In short, this requires emerging cooperative members to trust the management as they pursue objectives that involve building bridging social capital.

In addition to the obvious challenges of entering markets in a globalized economy, cooperatives in developing countries also face the challenge of not having existed long enough to develop a legacy of social capital underpinning adaptation to different challenges. While there was some indigenous development of cooperatives in the colonial period, the colonial masters essentially developed cooperatives to funnel raw agricultural commodities towards the colonising country for processing, leaving the African members with little control over the operation of their cooperatives (Holmen 1990).

The challenge of building social capital within these smallholder cooperatives, then, has typically fallen upon postcolonial governments, with the assistance of various international governmental and non-governmental aid organizations as is the case in Rwanda (Verhofstadt and Maertens 2014). The World Bank and other international development institutions have taken notice of and adopted a framework around social capital following the rise of literature on the topic in the 1990s, articulated in the writings of Woolcock and Narayan (2000). Their central point is that for development to succeed, emerging economies need to develop social capital. In an economic development context, bridging ties help social actors to diversify their stock of social capital, and it is, in many ways, analogous to Granovetter's (1973) notion of weak social ties. Actors with high levels of bridging social capital are more likely to receive information about economic opportunities and access to other resources with which to take advantage of those opportunities. The critical question, then is can bridging capital be developed where it is currently weak or absent?

A program by the Government of Rwanda to build agricultural cooperatives as a central element in the overall economic development plan for the country is especially relevant in testing the extent to which bridging social capital can be built. The Government of Rwanda has introduced an aggressive cooperative policy which is set within a larger framework that employs somewhat authoritarian methods to build civil society. The question addressed in this paper is, to what extent do smallholder farmers accept this model?

Because of the well-documented growth of the Rwandan economy and the apparent success of the government in overcoming the effects of the genocide of the 1990s, the government's efforts to build agricultural cooperatives provides a unique opportunity for research on the ability of governments and their international supporters to build social capital. The government's program in this area has received mixed reviews, with some observers praising it for its developmental success, while critics have charged that the program is in fact authoritarian, forcing farmers to participate in cooperatives (Gready 2010; Huggins 2014).
The project described below provides us with an opportunity to assess the extent to which cooperative members are supportive of the government's program and, most important, to measure the extent to which social capital is associated with overall member loyalty.

A cooperative seed development project initiated by the Government of Rwanda, with funding from USAID and technical assistance from Land $\mathrm{O}^{\prime}$ Lakes International Development, provides an opportunity to assess the relationship between social capital perceptions among cooperative members and their overall satisfaction with cooperative performance. The project was designed to utilize smallholder grain cooperatives as a mechanism to facilitate smallholder farmers' access to newer scientifically based technology that would improve their production and household income and, in turn, increase the efficiency of Rwandan agriculture as a whole. Cooperative members were asked to trust their cooperatives in the development of the latter in bridging social capital, as they connected to outside sources of farm supplies and technical assistance.

The specific focus of this project is to identify the impact of differing levels of trust that smallholder maize cooperative members have for input suppliers within the larger policy framework. Adopting new input approaches requires members, who lack formal training in agronomy, to accept the promise of more productivity and income, but with inputs with which they were not familiar. This paper focuses on the level of trust of cooperative members in the various organizations involved in the project, including the input suppliers - private seed and fertilizer companies, the Rwandan Cooperative Development Agency, and the cooperatives themselves, as well as the relationship between members' trust of those organizations and their overall satisfaction with their cooperatives.

\section{Methods}

The findings reported here are based on a quantitative survey conducted in 2015 on five maize cooperatives in Rwanda. Prior to the development of the survey instrument, focus groups were held with all cooperatives included in the study as well as representatives from two privately-owned agricultural input suppliers and a bank, which provides loans to cooperatives and members. The focus groups informed the survey instrument, which consisted of questions on members' levels of trust in the various organizations involved in the project as well as overall satisfaction with the cooperative.

\subsection{Focus groups and questionnaire development}

Focus groups were held prior to the development of the survey instrument to help in survey and question design and to help inform the research team of underlying levels of social cohesion. Each focus group was held on-site at each cooperative and was 
attended by cooperative members, those in leadership positions, the cooperative accountant and agronomist. Walking tours of the cooperatives and of some farms were conducted during this time as well. Variables were specifically included in the survey instrument to measure variations in levels of social capital and overall satisfaction with the cooperative.

The focus group plan followed a semi-structured list of topic questions, which focused on cooperative performance metrics (commodity outputs, proportion of yield sold versus consumed, the prevalence of hawkers [i.e. informal buyers], and member composition). Focus groups ranged in size from 8 to 15 members and included a mix of men and women, with the smallest proportion of women attendees being $30 \%$ and the largest being $60 \%$. In addition to identifying appropriate questions to include in the questionnaire, the research team was also interested in obtaining a view of the underlying social cohesion. Overall, both men and women participants spoke up about issues they faced and aspects of the cooperative they liked and disliked at approximately the same rate. Most importantly, women participants did not appear to be shy about voicing their opinions and took an active role throughout the process.

Table 1 provides an overview of all questions included in the bivariate analysis and models. Table 1 contains each variable name, a short description of what the variable measures, and the variable type.

\subsection{Cooperatives}

Three cooperatives are located in the East Province and two cooperatives were located in the South Province. Individual cooperatives are located in different districts and sectors within their respective provinces. Five different cooperatives were chosen in order to allow for variation in key variables of interest. Considering cooperatives with different founding dates is important as it relates to the CIP policy, implemented in 2007, as older cooperatives likely have different experiences with the government's implementation of the new policy than more recent ones. The oldest cooperative in the study was formed in June of 2009; the most recent cooperative was formed in September of 2013. Cooperatives were chosen at geographical locations in order to allow for the influence that different regional governmental bodies (i.e., district agronomist and RAB representatives) may have on member trust. Cooperatives were also chosen to account for further variation in the social and economic demographics and farming characteristics of the cooperatives. Province locations were chosen due to the tendency of cooperatives in the East and Southern provinces to grow maize.

\subsection{Sample}

A systematic random sampling design was used to select respondents from each cooperative in the study. A member registry list was obtained and a randomly selected starting point selected for each cooperative. A sample size of 50 respondents was taken from each cooperative for a total sample size of 250. In addition to the original 250-member sampling frame, a repository list of 20 respondents from each cooperative (100 total) was taken to serve as a bank of respondents in case any of the original 250 respondents opted not to be included in the study. Respondents were interviewed in-person by local persons trained in data collection techniques. The study had an opt-in rate of about $80 \%$, and the survey yielded a $100 \%$ completion rate. The sample included the demographic characteristics of cooperative members, including: age, gender, household structure and marital status. Research team members based in Rwanda identified ten survey enumerators, all of whom are Rwandan and fluent in Kinyarwandan. They underwent a training course that reviewed the purpose of the study, the questionnaire, and the sampling design. Enumerators were encouraged to answer respondent questions regarding the purpose of the survey and to make ad hoc adjustments to explanations of survey questions in the field when necessary.

\subsection{Net promoter score}

Two sets of measures were used in the study. The first, a measure of social capital, was measured using a Likert scale, with ' 1 ' being 'Not very trustworthy' to ' 5 ' being 'Very trustworthy' that provided an indication of the trust level of cooperative members toward specific persons or organizations that could provide information and support for their farm-level decisions. These included cooperative leadership, local leaders, government agencies responsible for cooperatives, private sector input suppliers, relatives and religious leaders.

The second measure was the Net Promoter Score (NPS), which was used as an indicator of members' overall level of satisfaction with their cooperative. The NPS was developed to measure customer and firm satisfaction (Reichheld 2003) and has been used to indicate member loyalty in a variety of organizational contexts - private sector, non-governmental, and governmental (Delgado-Ballester and Luis Munuera-Alemán 2005).

The first step in creating a NPS is to ask the following question: "On a ten-point scale, with 1 being low and 10 being high, how likely is it that you would recommend this organization to a friend or colleague?" (Reichheld 2003). Responses are then recoded into three nominal categories: ' 0 ' to ' 6 ' are coded as 'detractors'; '7' and ' 8 ' are coded as 'passives'; and ' 9 ' and ' 10 ' are coded as 'promoters.' Then the percentage of 'detractors' is subtracted from the percentage of 'promoters' to provide the NPS score. Thus, NPS can range from -100 to 100 . In this study, NPS is used to measure cooperative member satisfaction and loyalty. For the purposes of this study, respondents were categorized into 'detractors', 'passives' and 'promoters' in Fig. 3 and the subsequent discussion. We keep the variable original structure, measuring from 1 to 10 for the Poisson regression model shown below in Table 3. Keeping the variable coded on a scale 
Table 1 Variable descriptions

\begin{tabular}{|c|c|c|}
\hline Variable name & Description & Type \\
\hline African seed company II & Regional agricultural firm based in East Africa & Likert $1-5$ scale \\
\hline African seed company I & & \\
\hline U.S. agro-chemical company & International agriculture research and supply firm & \\
\hline European agro-chemical company & Large, international agricultural firm specializing in fertilizer & \\
\hline Agro Dealer & Sells agriculture inputs & \\
\hline Rwanda Agriculture Board (RAB) & Agency that oversees and promotes agricultural development & \\
\hline Cooperative Management Committee & Oversees cooperative decisions, comprised of 6 to 10 cooperative members & \\
\hline Cooperative President & Elected leader of cooperative; cooperative member & \\
\hline Cooperative Manager & Handles day-to-day business in cooperative; cooperative member & \\
\hline Cooperative Agronomist & Lead agronomist for cooperative & \\
\hline Zone Leaders & Elected to represent cooperative sub zones, boundaries; cooperative member & \\
\hline Cooperative Accountant & Oversees cooperative finances. Usually college educated. Not a cooperative member & \\
\hline District Agronomist & Regional agronomist assigned to each administrative district & \\
\hline My village leaders & Local village leaders including formal and informal leadership & \\
\hline My relatives & Relatives, including primary and secondary & \\
\hline Sector Agronomist & Regional agronomist assigned to each administrative district & \\
\hline Radio & FM/AM Radio Broadcasters & \\
\hline Television & Local/cable television providers & \\
\hline My neighbors & Village or plot neighbors & \\
\hline My church or mosque & Center of worship if applicable & \\
\hline Gender & Reference is man & Nominal; asked binary \\
\hline $\begin{array}{l}\text { Marital status } \\
\quad \text { (married is reference) }\end{array}$ & Reference is married & $\begin{array}{l}\text { Nominal; Married, } \\
\text { single and widowed }\end{array}$ \\
\hline Age & Respondents were asked their age in years & Continuous \\
\hline Cooperative & Coop 1 is reference; 5 Cooperatives, 50 sampled from each. & Nominal \\
\hline NPS & Net Promoter Score & Count, scale of 1 to 10 \\
\hline
\end{tabular}

from 1 to 10 for modelling - instead of categorising it - allows for more power and precision in the model (Harrell Jr 2015).

Three statistical approaches are provided in the following section. First, univariate descriptive analysis is provided, along with an approximation of each cooperative's location, presented in Fig. 2. Bivariate statistics are presented in Figs. 3 and 4 as well as in Table 2. For Fig. 3 and Fig. 4, a series of chi-square tests of independence have been run on each variable and their respective dependent variables, gender and NPS category. Table 2 is analysed using the F-distribution and global test of significance. Table 3 shows each of the four equations used in statistical modelling. The model used is a Poisson regression model, which is an appropriate and robust approach to modelling count data (Coxe et al. 2009). A Poisson regression model has the following form:

$\log \log (E(x))=a+B^{\prime}(x)+e$

The four models are implemented in a series of equations listed across the top of each column. The coefficients show the strength of the relationship between trust in a specific organization or other entity as well as the direction of that relationship, i.e., either positive or negative. Results are presented in a block design with each equation including the new coefficients in addition to the preceding equation. Model coefficients are standardized and values less than 0 indicate a negative impact while values over 0 indicate a positive impact.

\section{Results}

\subsection{Overall descriptive statistics}

Figure 2 shows a map of the approximate locations of the cooperatives included in the study. Cities or large towns, with populations of 10,000 or more, are included as well as the capital, Kigali. District boundaries, which specify intermediate administrative geographies, are depicted within the base map. The cooperatives are spread out geographically between districts, with no two cooperatives occupying the same district. No cooperative is in close proximity to the mountains in the north or lake region in the west. 


\section{Locations are approximate.}

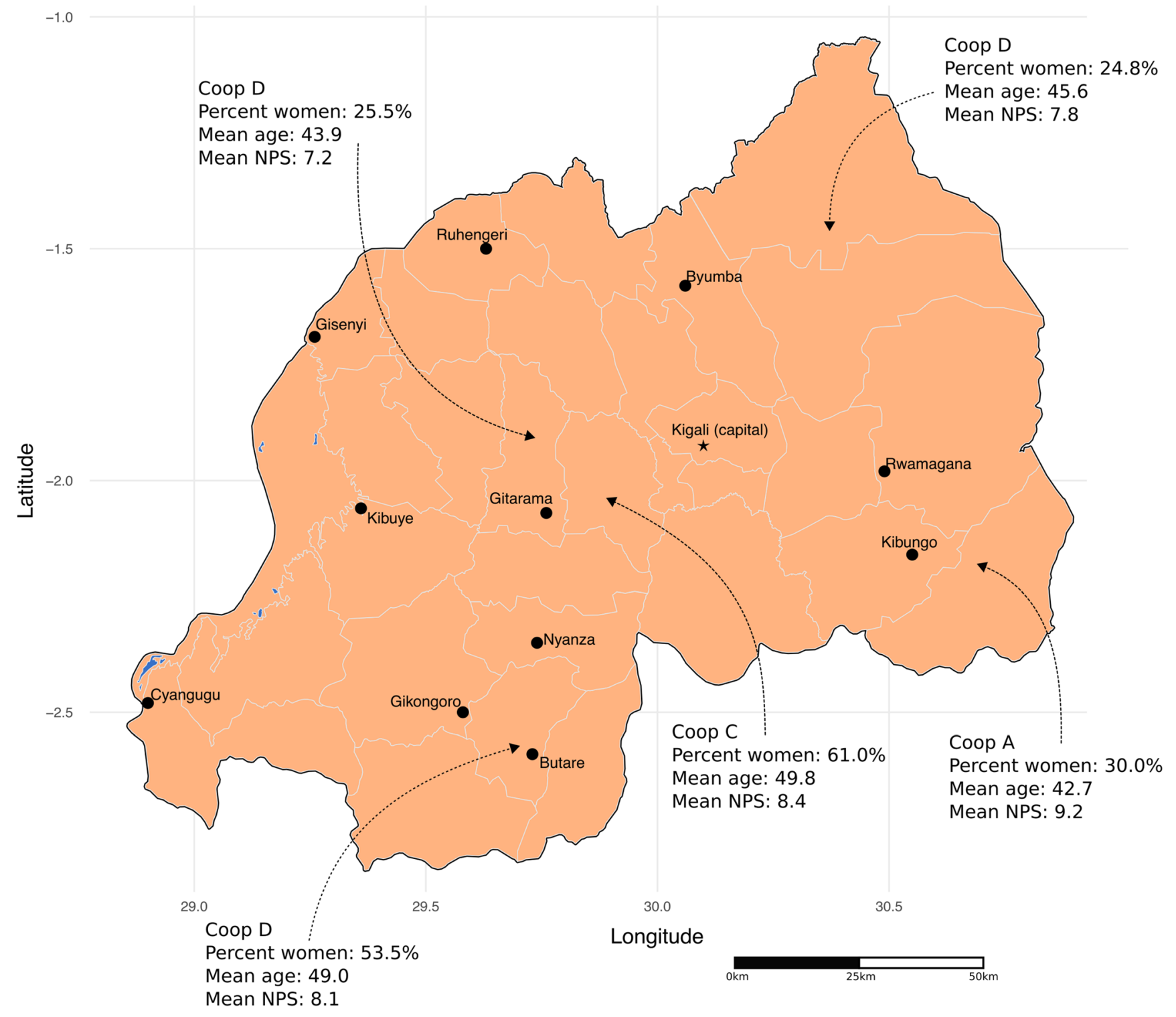

Map created by Elliot Meador \& David O'Brien

Data obtained from National Institute of Statistics of Rwanda ${ }^{\odot} 2018$

Mapped using R: A Language and Environmentfor Statistical Computing

Points represent cities of population 10,000 or more.

Fig. 2 Cooperative location, description and proximity to urban areas. Locations are approximate

Figure 2 provides a descriptive analysis of the percent of women, mean age and mean NPS for each cooperative. The percentage of women members varies considerably between cooperatives, from Cooperative D having just under a quarter of woman membership to Cooperative E, which has $53.5 \%$ women membership. The mean ages for cooperatives range between about 42 to just under 50 years. The average NPS score (on a 10-point scale) ranges between 7.21 and 9.17 with Cooperative B having the lowest NPS mean score and Cooperative A having the highest.

\subsection{Members' levels of Trust of Different Sources of information}

Figure 3 shows the members' level of trust of cooperative leadership, various sources of information and support for their farm activities for the total sample and by gender. In Fig. 3 the black line represents mean women trust levels, while the grey line represents trust levels of men. Respondents were asked to rate their level of trust on 20 different individuals and organisations that associated with their agriculture and their cooperative. These 20 items have been grouped as: 1) 


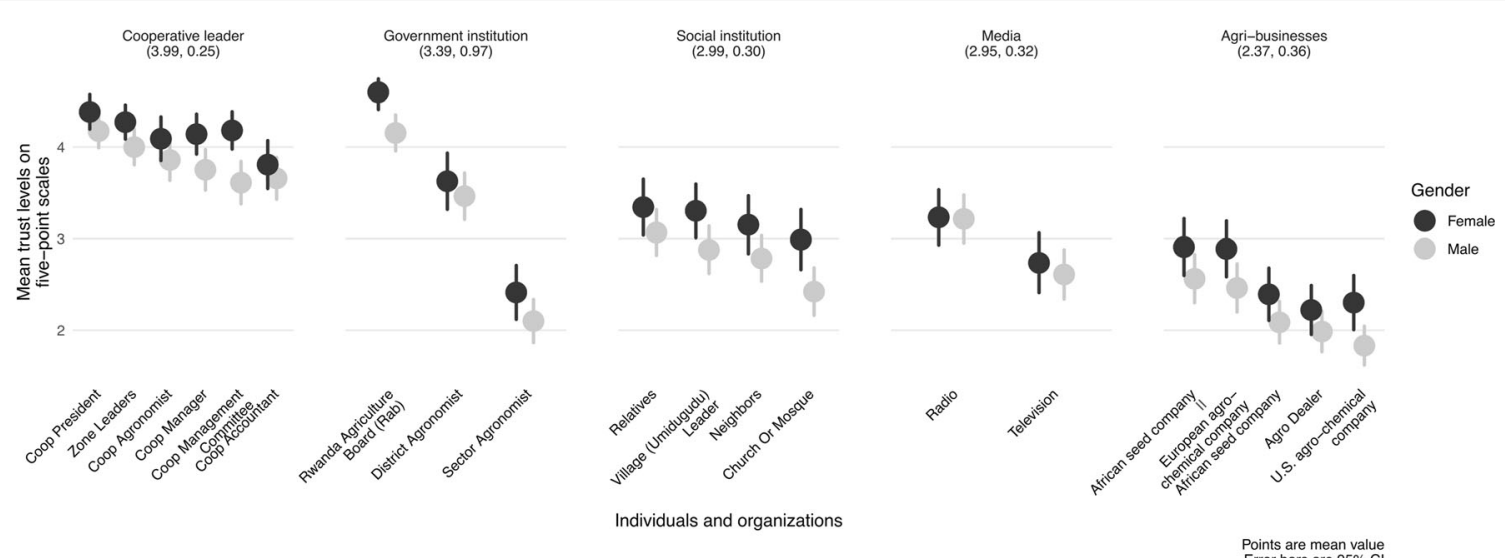

$\begin{array}{r}\text { Points are mean value } \\ \text { Error bars are } 95 \% \mathrm{Cl}\end{array}$
Group mean and standard deviation are shown below facet labels

Fig. 3 Cooperative Members' Trust of Specific Organization and individuals - Total Sample and by Gender. Scale -1 to 5, with $5=$ highest level of trust. Error bars are $95 \%$ CI. Test of significance conducted using chi-square $* p<0.05 ; * * p<0.01 ; * * *<0.001$

Cooperative leader; 2) Government institution; 3) Social institution; 4) Media; and, 5) Agri-business. An overall group mean and standard deviation is shown beneath the group labels. Figure 3 shows important differences between the levels of trust from men and women; in general, women are more trusting than men, with women having an overall average trust of $3.35(\mathrm{SD}=1.6)$ and men having an overall average trust of $3.00(\mathrm{SD}=1.6)\left[\chi^{2}(2)=56.22, p<.001\right]$.

Overall, respondents have the highest level of trust in the Rwanda Agriculture Board (RAB), the governmental agency in charge of developing cooperatives and integrating their operations into the larger economic development plan for agriculture; a score of $4.32(\mathrm{SD}=1.1)$ on a scale of 1 to 5 . Close behind are the mean levels of trust in the officers of the cooperative; levels of trust then decline with the district agronomist, to the radio, village leaders, churches, neighbours, television and private sector seed suppliers. The lowest mean score of 2.0 was given to a seed supplier that is a subsidiary of an international agro-chemical company. The highest ratings were given to the governmental agency and the cooperative leadership, which runs counter to the critics' claim of the lack of support among members for the cooperatives.

In general, the trend lines for both women and men members show high levels of trust in government agriculture institutions and cooperative leadership. There is less overall trust in input suppliers for both women and men. Chi-square tests indicate that women members have higher trust in four specific areas: the Rwanda Agricultural Board; cooperative managers; the cooperative management committee, and the European Agro-Chemical Company.

\subsection{Overall level of loyalty to the cooperative}

Of the 250 respondents among the five cooperatives, there were 146 promoter cooperative members (i.e., respondents who answered a 9 or 10 to the question 'Would you recommend the cooperative to a friend or relative?' $1-10$ ), or $58.3 \%$; there were 66 passive cooperative members, or $26.2 \%$; and there were 38 detractor cooperative members, or $15.5 \%$. The proportional difference between promoter type and cooperative is statistically significant at the 0.01 alpha level $\left.\left[\chi^{2}(8)=20.71, p<.01\right)\right]$.

The age of cooperative members was given careful consideration in the study, since different age cohorts may have had quite different experiences with respect to the genocide and the way that it affected their view of cooperatives which were framed within the government's mandate to encourage multiethnic participation in each individual local organization.

The mean age for all respondents in the sample was 46.5 , with a standard deviation of 12.29; the mean age for women was 47.12 , with a standard deviation of 11.79; and the mean age for men was 46.05, with a standard deviation of 12.67 . The difference in mean age between women and men was just over 1 year and is not statistically significant $(1.1, P=0.431)$.

The mean age for cooperative promoters was 47.02 , with a standard deviation of 12.92 ; the mean age for cooperative passives was 45.29 , with a standard deviation of 10.31 ; and the mean age for cooperative detractors was 46.63 , with a standard deviation of 13.1. The difference between net promoter means is not statistically significant $(P=0.633)$.

The mean age for cooperative members who are married was 45.78 , with a standard deviation of 12.01 ; the mean age for cooperative members who were widows was 53.61, with a standard deviation of 10.49; and the mean age for cooperative members who were single was 33.5 , with a standard deviation of 8.22 . The difference between the mean age of marital status is statistically significant $(P=0.049)$. Marital status and mean NPS scores are shown in Table 2 along with frequency rates and standard errors.

The respondents who were single (i.e. not married or widowed) constitute the largest proportion of net promoters from any group at about $90 \%$ with a mean of 9.60 ; the remaining (about 10\%) were classified as passive members. The proportion of single net promoters was substantially higher than both married and widowed members. However, the total number of respondents who were single in the total sample was quite low, with a total of only 10 respondents in this category. 


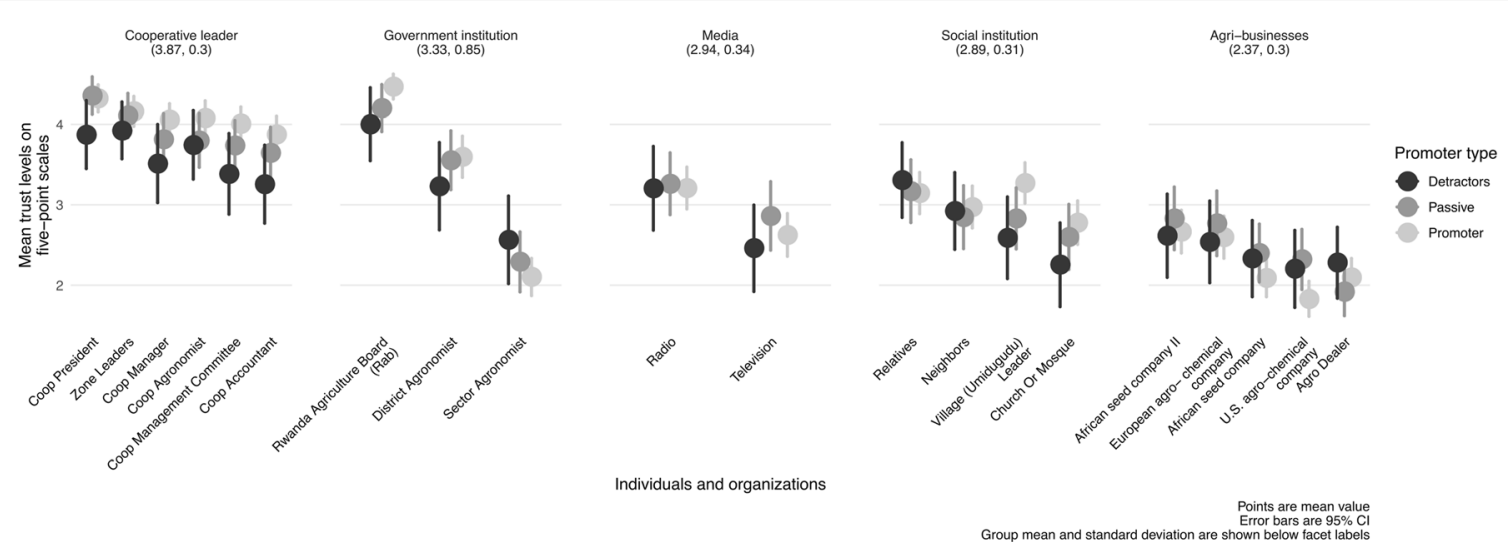

Fig. 4 Trust of individuals and organizations by three promoter types (DP) Scale -1 to 5 , with $5=$ highest level of trust. Error bars are $95 \%$ CI. Test of significance conducted using chi-square $* p<0.05 ; * * p<0.01 ; * * *<0.001$

The percentage of net promoters among widows was $60 \%$, with a mean of about 8.55 ; the percentage of married respondents classified as net promoters was about $56 \%$, with a mean of 8.09. Furthermore, the highest proportions of detractors were individuals who were married, at $18.1 \%$; widows had the lowest proportion of detractors with just over $7 \%$. The proportional difference between all levels in marital status and promoter type is not statistically significant $\left[\chi^{2}(4)=8.01, p=\right.$ $0.066]$. The difference in promoter score between men and women is small, 0.5 , which is not statistically significant $\left[\chi^{2}\right.$ (10) $=12.21, p=0.271]$.

\subsection{Multivariate tests showing the impact of social capital trust on net promoter scores}

Multivariate analysis was conducted to enable a further understanding of the impact that social capital has on the likelihood that a cooperative member is a Net Promoter. Trust scores are used in a Poisson regression model to predict Net Promoter scores. -.

Figure 4 shows the mean levels of trust for cooperative 'detractors', 'passives' and 'promoters.' Trust items have been grouped as: 1) Cooperative leader; 2) Government institution; 3) Social institution; 4) Media; and, 5) Agri-business. An overall group mean and standard deviation is shown beneath the group labels. The general trend is similar to that of Fig. 3. On average, 'detractors', 'passives' and 'promoters' tend to have higher levels of trust in the cooperative leadership than in private input suppliers. The error bars show the $95 \%$ confidence intervals of parameter estimates between the three promoter types in their levels of trust for each category of individuals and organizations. A noteworthy finding, though not statistically significant according to the chi-square tests, is the "promoters" higher levels of trust towards the cooperative president, agronomist, accountant and village leaders, compared to the "passives" and the "detractors". Figure 4 shows that, overall, 'promoters' report nominally higher levels of trust around cooperative leadership, while 'detractors' have the highest levels of trust in agricultural input suppliers.

Table 3 shows the results of four Poisson regression models, indicating how trust in different sources of agricultural information are associated, either positively or negatively, with overall member loyalty to the cooperative. A discussion of each equation is presented in the following sections.

\subsubsection{Equation 1: Input providers}

The first model includes input suppliers. As a respondent's trust increases in the U.S. agro-chemical company, his/her cooperative promoter score decreases. This trend is negative and significant throughout all four models. Alternatively, as a respondent's trust increases in the European agro-chemical company so too does his/her promoter score. This trend continues until the fourth model, where it disappears when demographics and cooperative are added.

\subsubsection{Equation 2: Cooperative management}

A high level of trust in the cooperative agronomist is positively associated with high promoter scores as is a high level of trust in the cooperative accountant. In addition, the Rwandan Agricultural Board has a positive and significant association with promoter score, and the sector agronomist has a negative and significant association with promoter score. The coefficient for the U.S. agro-chemical company remains negative.

Table 2 Marital status and net promoter type

\begin{tabular}{llll}
\hline Marital status & mean & freq & se \\
\hline Married $(n=197)$ & 8.09 & $79.3 \%$ & 0.19 \\
Single $(n=10)$ & 9.60 & $4.0 \%$ & 0.22 \\
Widow $(n=41)$ & 8.55 & $16.7 \%$ & 0.36 \\
Total & 8.23 & $100 \%$ & 0.16 \\
\hline
\end{tabular}

ANOVA: $F(3,=2.418), p=0.049$ 
Table 3 Poisson regression: predicting promoter score (1-10) by trust of specific organizations and individuals

\begin{tabular}{|c|c|c|c|c|}
\hline & $\begin{array}{l}\text { Equation } 1 \\
\log \text { (NPS) }\end{array}$ & $\begin{array}{l}\text { Equation } 2 \\
\log \text { (NPS) }\end{array}$ & $\begin{array}{l}\text { Equation } 3 \\
\log \text { (NPS) }\end{array}$ & $\begin{array}{l}\text { Equation } 4 \\
\log \text { (NPS) }\end{array}$ \\
\hline (Intercept) & $1.03 * * *$ & $1.27 * * *$ & $1.24 * * *$ & $1.15 * * *$ \\
\hline African seed company II & 0.1 & 0.06 & -0.06 & -0.02 \\
\hline African seed company I & -0.13 & -0.2 & -0.07 & -0.05 \\
\hline U.S. agro-chemical company & $-0.42 * *$ & $-0.39 *$ & $-0.42 * *$ & $-0.40 *$ \\
\hline European agro-chemical company & 0.23 & 0.21 & $0.32 *$ & 0.26 \\
\hline Agro Dealer & 0.05 & -0.13 & -0.02 & 0.04 \\
\hline Rwanda Agriculture Board (RAB) & & $0.42 * * *$ & $0.42 * * *$ & $0.39 * *$ \\
\hline Cooperative Management Committee & & 0.24 & 0.24 & 0.21 \\
\hline Cooperative President & & 0.04 & 0.04 & -0.07 \\
\hline Cooperative Manager & & 0.01 & -0.09 & -0.15 \\
\hline Cooperative Agronomist & & $0.32 *$ & $0.43 * *$ & $0.45 * *$ \\
\hline Zone Leaders & & -0.06 & 0.05 & 0.06 \\
\hline Cooperative Accountant & & 0.19 & 0.13 & $0.27 *$ \\
\hline District Agronomist & & 0.08 & 0.12 & 0.17 \\
\hline My village leaders & & & $0.43 * *$ & $0.42 * *$ \\
\hline My relatives & & & $-0.29 *$ & $-0.26 *$ \\
\hline Sector Agronomist & & & $-0.52 * * *$ & $-0.51 * * *$ \\
\hline Radio & & & -0.07 & 0.02 \\
\hline Television & & & -0.14 & -0.25 \\
\hline My neighbors & & & -0.12 & -0.21 \\
\hline My church or mosque & & & 0.25 & 0.11 \\
\hline Gender (reference is male) & & & & $0.29 *$ \\
\hline \multicolumn{5}{|l|}{ Marital status (married is reference) } \\
\hline Single & & & & $1.54 * *$ \\
\hline Widow & & & & 0.34 \\
\hline Age & & & & 0.01 \\
\hline \multicolumn{5}{|l|}{ Cooperative (Coop 1 is reference) } \\
\hline Coop 2 & & & & $-0.41 *$ \\
\hline Coop 3 & & & & -0.33 \\
\hline Coop 4 & & & & -0.16 \\
\hline Coop 5 & & & & 0.35 \\
\hline Observations & 248 & 248 & 248 & 248 \\
\hline Cox-Snell Pseudo $\mathrm{R}^{2}$ & 0.176 & 0.279 & 0.38 & 0.489 \\
\hline Nagelkerke Pseudo $R^{2}$ & 0.177 & 0.282 & 0.383 & 0.495 \\
\hline-2 Log-Likelihood & 1109.113 & 1075.777 & 1038.572 & 990.474 \\
\hline
\end{tabular}

$* p<.05 * * p<.01 * * * p<.001$

\subsubsection{Equation 3: Relatives and community members}

Equation three adds variables that measure trust in the village leader, relatives and neighbors and church or mosque. High levels of trust in one's relatives are associated with low promoter scores, while trust in one's village leader is associated with high promoter scores. Covariates from equations one and two remain unchanged.

\subsubsection{Equation 4: Controls}

Equation four adds gender and other control variables to the model. Marital status and gender are statistically significant in the overall model. Single respondents are more likely to have higher promoter scores than married respondents. There is no difference statistically for widowed respondents and married respondents. Women respondents are more likely to have positive promoter scores than their male counterparts.

\subsection{Model fit}

The model fit was assessed using both the Cox-Snell and Nagelkerke pseudo $R^{2}$ values. These values are analogous to the $R^{2}$ in an ordinary least squares regression. There is a progressive increase in both measures of model fit for each model. With the full model, eq. 4, explaining close to $50 \%$ of the total variance. In addition, the -2 Log-Likelihood statistic is provided for each equation. In general, the -2 Log-Likelihood decreases with each iteration of the model, which suggest better model fit for each iteration.

\section{Conclusions}

The analysis presented above provides some clarification of the mixed reviews of the Rwandan cooperative model. At a minimum, there were more "promoters" of the cooperatives than there were either "passives" or "detractors." Most telling 
is the observation that higher levels of support for the cooperative were associated with high levels of trust in the government agency that provides subsidies for maize and is most directly responsible for cooperative policy, the Rwandan Agricultural Board, as well as cooperative leadership and technical advisors, including the cooperative agronomist and accountant. These positive associations would seem to provide support for the overall Government of Rwanda plan of utilizing the cooperative as a primary vehicle for bringing smallholder members into scientific agriculture and eventually the global agro-business system. These relationships, then, provide convincing evidence that it is possible to create bridging social capital if the cooperative itself, as well as its government sponsor, has generated high levels of bonding social capital among its members.

Conversely, the smaller number of detractors tend to place greater trust in less expansive relationships, such as their own relatives, as well as the private sector input providers, especially a multi-national American based company.

Finally, and perhaps most importantly, the willingness of individual cooperative members to express quite high levels of trust in specific organizations and entities, including their own cooperative presents a very different picture of political life from that presented by the government's most severe critics. These findings do not discount the authoritarian elements in the government's policies, but rather note that apparently a substantial portion of the Rwandan citizenry, at least in the agricultural sector appears to be satisfied with the program, especially women.

The results provide strong evidence that the Government of Rwanda's agriculture policies, although authoritarian in nature, are providing farmers in maize cooperatives with stability in market access that coincides with high levels of member trust in cooperative leadership. Moreover, the policy of requiring women participation in leadership positions within cooperatives appears to be working. While no causal relationship between symbolic inspiration and women leadership should be made based on this study, it is noteworthy that women cooperative members do have higher overall net promoter scores than their male counterparts. Furthermore, women participants have higher levels of trust in almost all measured variables than their male counterparts (see Fig. 3, Section 5).

In regard to the question of whether or not this approach to food policy in developing countries is sustainable or not remains to be seen in Rwanda. Clearly, Rwanda is unique in terms of the absolute disruption of all political, economic and social institutions following the genocide in 1994. In 2016, the constitutional changes were made to allow President Kagame to run for another presidential term, which he won in an overwhelming victory - without any real opposition. These changes allow the current president to remain in office until 2033, if he should be successful in reelection. Certainly, it seems that agricultural policy in Rwanda is tied to the current regime, and, any change in this regime may result in significant policy changes. Moreover, given the authoritarian nature of the current regime, there is likely to be some degree of fear of repercussions associated with speaking out against the government. Although the extent to which fear of speaking out influences the results is difficult to quantify, it should not be discounted. The critical question that remains to be answered is, what will happen in the post-Kagame era? Therefore, results presented in this paper are not appropriate to judge the effectiveness of these policies in the long run; in the short run, however, they appear to be working.

Subsequent studies on Rwanda agricultural policies should focus on differences in social capital and promoter scores between individual cooperatives as well as the efforts of the model to link locally-based primary cooperatives to more complex federated organizational structures. Linking primary cooperatives with federated representation to foreign markets is a policy ambition for the Government of Rwanda. Linking cooperatives with wider representation in federated cooperatives means that there must be a high level of bonding and bridging social capital present, as trust will be a key component in this task.

Acknowledgements This project is funded by the United States Agency for International Development (US) (AID-OAA-A-10-00016).

\section{Compliance with ethical standards}

Conflict of interest The authors declared that they have no conflict of interest.

Open Access This article is distributed under the terms of the Creative Commons Attribution 4.0 International License (http:// creativecommons.org/licenses/by/4.0/), which permits unrestricted use, distribution, and reproduction in any medium, provided you give appropriate credit to the original author(s) and the source, provide a link to the Creative Commons license, and indicate if changes were made.

\section{References}

Burnet, J. E. (2008). Gender balance and the meanings of women in governance in post-genocide Rwanda. African Affairs, 107(428), 361-386. https://doi.org/10.1093/afraf/adn024.

Burnet, J. E. (2011). Women have found respect: Gender quotas, symbolic representation, and female empowerment in Rwanda. Politics \& Gender, 7(3), 303-334. https://doi.org/10.1017/ S1743923X11000250.

Clark, P. (2018). Rwanda's recovery: When remembrance is official policy. Foreign Affairs, 97, 35.

Coleman, J. S. (1988). Social Capital in the Creation of human capital. American Journal of Sociology, 94(1988), S95-S120.

Cook, M. L. (1995). The future of U.S. agricultural cooperatives: A neoinstitutional approach. American Journal of Agricultural Economics, 77(5), 1153. https://doi.org/10.2307/1243338.

Cook, M. L., \& Burress, M. J. (2013). The impact of CEO tenure on cooperative governance. Managerial and decision economics, 34(3-5), 218-229. 
Coxe, S., West, S. G., \& Aiken, L. S. (2009). The analysis of count data: A gentle introduction to Poisson regression and its alternatives. Journal of Personality Assessment, 91(2), 121-136.

Delgado-Ballester, E., \& Luis Munuera-Alemán, J. (2005). Does brand trust matter to brand equity? Journal of Product and Brand Management, 14(3), 187-196. https://doi.org/10.1108/ 10610420510601058.

GINI index (World Bank estimate). (n.d.). Retrieved from https://data. worldbank.org/indicator/si.pov.gini. Accessed 25 July 2019.

Granovetter, M. (1973). The strength of weak ties. American Journal of Sociology, 78(6), 1360-1380.

Gready, P. (2010). "You're either with us or against us": Civil society and policy making in post-genocide Rwanda. African Affairs, 109(437), 637-657.

Harrell Jr, F. E. (2015). Regression modeling strategies: With applications to linear models, logistic and ordinal regression, and survival analysis. Springer.

Harrison, G. (2016). Rwanda: An agrarian developmental state? Third World Quarterly, 37(2), 354-370.

Holmen, H. (1990). State, cooperatives and development in Africa. Uppsala: Nordic Africa Institute.

Huggins, C. (2009). Agricultural policies and local grievances in rural Rwanda. Peace Review, 21(3), 296-303.

Huggins, C. (2014). "Control grabbing" and small-scale agricultural intensification: Emerging patterns of state-facilitated "agricultural investment" in Rwanda. The Journal of Peasant Studies, 41(3), 365-384.

Kathiresan, A. (2011). Strategies for sustainable crop intensification in $R w a n d a$. Shifting focus from producing enough to producing surplus, $1-59$.

Meador, J. E., O’Brien, D. J., Cook, M. L., Grothe, G., Werner, L. A., Diang'a, D., \& Savoie, R. M. (2016). Building sustainable smallholder cooperatives in emerging market economies: Findings from a five-years project in Kenya. Sustainability (Switzerland), 8(7).

O’Brien, D. J., Banwart, L., \& Cook, M. L. (2013). Measuring the benefits of smallholder farmer membership in producer-controlled vertical value chains: Survey findings from a development project in East Africa. Poverty and Public Policy, 5(4), 399-416. https://doi. org/10.1002/pop4.50.

Prunier, G. (2008). Africa's world war: Congo, the Rwandan genocide, and the making of a continental catastrophe. Oxford University Press.

Putnam, R. D. (1995). Tuning in, tuning out: The strange disappearance of social capital in America. PS: Political science \& politics, 28(4), 664-683.

Reichheld, F. F. (2003). The one number you need to grow. Harvard Business Review, 81(12), 46-54+124. https://doi.org/10.1111/j. 1467-8616.2008.00516.x.

Schneiberg, M., King, M., \& Smith, T. (2008). American insurance, dairy, and grain industries all use subject to JSTOR terms and conditions social movements and organizational form : Cooperative alternatives to in the American insurance, corporations dairy, and grain industries. American Sociological Review, 73(4), 635-667.

Straus, S., \& Waldrof, L. (Eds.). (2011). Remaking Rwanda: State building adn human rights after mass violence. Madison: University of Wisconsin Press.

Verhofstadt, E., \& Maertens, M. (2014). Smallholder cooperatives and agricultural performance in Rwanda: Do organizational differences matter? Agricultural Economics (United Kingdom), 45(S1), 39-52.

Warner, G. (2016). It's The No. 1 Country For Women In Politics - But Not In Daily Life. Retrieved from https://www.npr.org/sections/ goatsandsoda/2016/07/29/487360094/invisibilia-no-one-thoughtthis-all-womans-debate-team-could-crush-it?t=1563182385791. Accessed 08 Dec 2019
Woolcock, M., \& Narayan, D. (2000). Social Capital: Implications for Development Theory, and Policy. World Bank Research Observer, 15(2), 225-249.

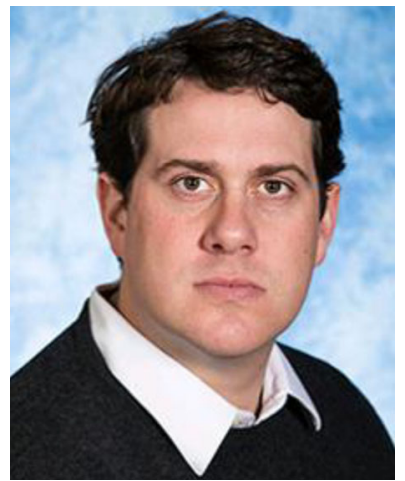

John Elliot Meador, Prior to joining SRUC's Rural Policy Centre in November 2015 Dr. Meador held a research post at the University of Missouri specialising in community economic and entrepreneurial development. As a researcher of rural economy and society his responsibilities included: Developing innovative research methodologies that will shed light on the role that collective action plays in economic development organisations in Scotland; Modelling social networks and their impact on community economic development; and Reviewing and analysing secondary data sources on community resilience and empowerment. His main areas of interest fall under the umbrella of collective action and social capital frameworks. He has two areas of focus: (1) rural economic development in the UK and US; and, (2) value chain integration with small holder dairy and maize cooperatives in Ethiopia, Rwanda, Kenya and Uganda. His research in the UK and US looks at social capital, measured empirically through social network analysis, and how it can be developed to increase community organisation capacities. The work is a continuation of his research in Africa, which looks at social networks and the impact they have on the adoption of hybrid maize seeds and value chain integration.

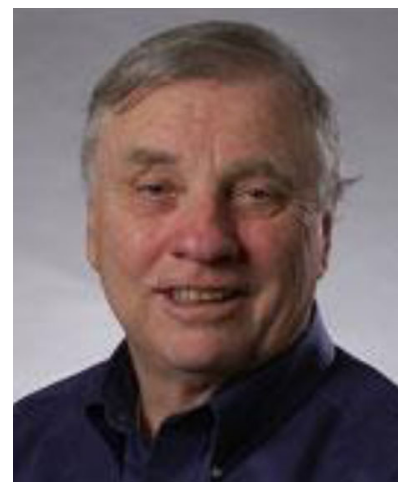

David O'Brien, Professor O'Brien is a professor of Rural Sociology at the University of Missouri-Columbia and also serves as a research consultant on survey research projects in developing countries. His early research examined grassroots efforts to organize urban neighbourhoods to improve residents' quality of life (D. J. O'Brien, Neighborhood Organization \& Interest Group Processes, Princeton University Press, 1975, 2016). This was followed by a long-term study, with Stephen Fugita, of Japanese Americans' inter-generational ethnic community attachment and assimilation into the larger multi-ethnic communities in which they live (S. S. Fugita and D. J. O'Brien, Japanese American Ethnicity: The Persistence of Community, University of Washington Press, 1991). Beginning in 1989, shortly before the collapse of the Soviet Union, Professor O'Brien began working on sample surveys of Russian rural household adaptation to market reforms (D. J. O'Brien \& V. V. Patsiorkovsky, Measuring Social and Economic Change in Rural Russia: Surveys from 1991 to 2003 Lexington Press, 2006). Most recently, Professor O'Brien has been working on the Local Works Program, sponsored by the United States Agency for International Development. This program is about investing in the creativity and resourcefulness of local communities and enabling them to drive their own development. 